\title{
RESUMO
}

Com a crise da representaçāo, a literatura do século XX deixa de ser a narrativa descritiva de relatos e acontecimentos, volta-se para a própria linguagem literária, problematiza o lugar e as relaçōes autor-narradorleitor e rompe com a estrutura narrativa e os valores da tradiçāo literária brasileira. Este artigo busca delinear os limites entre ficção e realidade a partir do estudo do multiperspectivismo narrativo em Os sertōes, de Euclides da Cunha e O bruxo do Contestado, de Godofredo de Oliveira Neto.

PALAVRAS-CHAVE: literatura brasileira, multiperspectivismo narrativo.

\section{Canudos e Contestado: A RUPTURA NA TRADIÇÃO LITERARIA BRASILEIRA}

\section{Mayara Ribeiro Guimarāes*}

\begin{abstract}
Alsstract
With the crisis in representation, the XXth century literature changes its narrative focus on facts to the literary discourse. The status of the authornarrator-reader, and their interconnection, is shaken. Literature alters its narrative structure and begins to question the values of the brazillian literary tradition. The article focus on highlighting the boundary between fiction and reality by the study of the narrative pluriperspectivism in $\mathrm{Os}$ Sertöes by Euclides da Cunha and $O$ bruxo do Contestado by Godofredo de Oliveira Neto.
\end{abstract}

KEY wORDS: Brazilian literature, narrative pluriperspectivism.

* Doutoranda em Literatura Brasileira na Universidade Federal do Rio de Janeiro. E-mails mayribeiroenol.com.br 
Na crítica literária européia, bem como na brasileira, o Realismo literário, disseminado nos moldes da literatura do século XIX, surge como uma corrente literária que torna a literatura um documento da realidade de uma época, dificultando a distinção entre ficção e realidade e tornando o fato um simulacro do real. A ficção que abrange o período do Romantismo e se estende até o Realismo busca ser o reflexo de uma realidade sensível, de modo que o elemento social externo se reduza ao elemento ficcional interno, elaborando uma literatura que se afirme como documento.

Por meio dos valores estéticos e morais ficcionalizados nos romances realistas, essa geração de escritores empenhou-se em praticar uma literatura de valor documental e histórico, cuja intenção subliminar era produzir criticas sociais que fossem amplamente veiculadas (VALERY, 1999, p. 77). Dessa maneira, a realidade construida em um texto tinha como base os dados oferecidos pelos documentos históricos, conquistando, desse modo o estatuto de documento, uma vez que revelava com riqueza de detalhes o "real" daqueles tempos. Buscava-se nāo a invençāo de uma realidade, mas a representação fidedigna de uma sociedade humana e orgânica do século XIX.

O Realismo, ao trabalhar com a enunciação de um referente que define a realidade a partir de sua representação, realiza a mimesis da sociedade relatando com autenticidade e verossimilhança as experiências individuais e o código da burguesia do século XIX. Com isso, a crítica realista à representação mimética torna-se uma crítica à ordem capitalista. Se, no fim do século XIX, imperava um realismo crítico, cuja função era a de representar o mundo para em seguida combatê-lo, a partir de uma narrativa representativa da burguesia ascendente, o século XX traz à cena a crise da representação que, inevitavelmente, abala as bases do Realismo literário, provocada, entre outros fatores, pela crise do autor apontada por Barthes. Se o autor, bem como uma teoria da literatura, é construção cultural, herança do fim da Idade Média, a literatura realista fica órfá do autor. Assim, o interesse deixa de ser a narrativa descritiva de relatos ou de fatos e acontecimentos, isto é, a história ou História, e se volta para a própria linguagem literária, retirando de cena a voz do autor e colocando a voz da própria linguagem. Como aponta Barthes (1988, p. 66):

na França, Mallarmé [...] viu e previu em toda a sua amplitude a necessidade de colocar a própria língua no lugar daquele que dela era até então considerado proprietário; para ele, como para nós, é a linguagem que fala, não o autor; escrever é [...] atingir esse ponto onde só a linguagem age, "performa", e não "eu": toda a poética de Mallarmé consiste em suprimir o autor em proveito da escritura [...]. 
No entanto, antes de Barthes anunciar suas idéias no fim da década de 1960, alguns autores, já desde o início do século XX, problematizavam o lugar do autor, a relação com o narrador e com o leitor.

Este artigo se dividirá em duas partes. A primeira tratará da instância do narrador múltiplo e de como o real é transformado por meio do multiperspectivismo narrativo elaborado por Euclides da Cunha em Os sertões, publicado em 1902 e, ainda, de que maneira o problema História x ficção é levado a cabo pelo autor na narrativa da guerra que tomou conta do povoado de Canudos em 1897. A segunda parte tratará dos limites entre realidade e ficção no romance de Godofredo de Oliveira Neto, intitulado O bruxo do Contestado, que tem como ponto de partida a Guerra do Contestado, ocorrida na região de Contestado em 1912, no sul do Brasil. Para tal, a composição narrativa será dividida em dois planos estruturais, o dos paratextos presentes antes e depois do romance e que contribuem para a compreensão da obra, bem como a relação autor-narrador elaborada ao longo das narrativas.

\section{EUCLIDES DA CUNHA: O POLIGRAFO dO BRASIL}

Em 1896, na região de Canudos, no sertão da Bahia, inicia-se a Guerra de Canudos, na qual dezenas de milhares de pessoas morreram, entre soldados e civis. Por três vezes, a força do exército brasileiro foi derrotada por um bando de indigentes, fanáticos religiosos, seguidores de um líder "delirante" e eloqüente, que, naquele período, era considerado apenas um monarquista retrógrado, um "falso apóstolo", fruto da "sociedade que o criou". As palavras de Euclides da Cunha (2001, p. 252), em sua principal obra publicada em 1902 , Os sertões ecoam as vozes do cientificismo, do positivismo e dos demais discursos de sua época, com a intençāo de denunciar o racismo e o reacionarismo da elite dominante explícitos tanto na descrição de Antonio Conselheiro, no capítulo "O homem" como na narração do capítulo intitulado "A luta".

A crítica literária euclidiana, desde o artigo de Araripe Júnior publicado em 1903, que aponta as aproximações entre o conteúdo histórico e o ficcional na obra de Euclides, estabelecendo conexōes com a obra historiográfica de Xenofonte (VALENTE, 1998, p. 40) e as obras literárias de Flaubert e Walter Scott, assinala a dupla inscrição da obra euclidiana e a dificuldade de sua classificação entre os gêneros literários. Tal dificuldade, no entanto, constitui um falso problema, já que o que importa é o conteúdo e a forma em que a narrativa se desenrola.

Na tentativa de avaliar o conteúdo ficcional de Os sertôes, acredito que a grande inovação de Euclides da Cunha reside na elaboração do estatuto do narrador desenvolvido na obra. Para estudá-lo é necessário observar, além 
da narrativa em si, a função dos paratextos apresentados por Euclides e que envolvem: a "Nota preliminar"; um mapa do estado da Bahia intitulado "Esboço geológico", de autoria de diversos pesquisadores; um mapa do sertão de Canudos; um mapa da vegetação baiana intitulado "Distribuição da flora sertaneja" e um quarto mapa preparado pela Comissão de Engenharia da última expedição intitulado "Canudos e suas cercanias"; e um desenho de trecho das caatingas, dentro do capítulo "A terra". Incluem-se também nos paratextos três fotografias, todas de autoria de Flávio de Barros: a primeira da base de operação dos soldados em Monte Santo; a segunda do acampamento dentro de Canudos; e a terceira, a mais conhecida, a foto das prisioneiras canudenses, com suas crianças, logo depois de serem capturadas pelos soldados do exército. De todos esses paratextos, no entanto, aqueles que mais nos interessam e serão abordados neste trabalho são a "Nota preliminar" e o mapa do estado da Bahia.

Segundo a corrente do Novo Historicismo, introduzida por Hayden White, as narrativas históricas que recontam o passado são também um ato interpretativo, já que os eventos históricos são transformados e recriados pela imaginação e pelas técnicas narrativas do historiador, técnicas estas que mais se aproximam das ficcionais, por maior pesquisa objetiva que haja. Luis Fernando Valente (1998, p. 41) aponta que "ele [White] propõe [...] que os eventos históricos não constituem automaticamente a história, mas são transformados na história pelo historiador, através de técnicas análogas àquelas utilizadas pelo ficcionista". Assim, o conhecimento da realidade humana passaria pelo imaginário e o ato de transformar o passado em história se aproximaria do ato poético e de uma perspectiva subjetiva e envolvida, de modo que a história pudesse reatar os laços de proximidade com a literatura. Assim sendo, Valente lê a obra de Euclides a partir da ótica do Novo Historicismo e não da ótica de um Neo-Realismo literário.

Mas não seriam as propostas levantadas pelo Novo Historicismo um pouco semelhantes àquelas elaboradas pelo Neo-Realismo literário? No NeoRealismo, a problematização entre o real e o imaginário delimita uma fronteira muito tênue entre, por exemplo, conteúdo histórico e conteúdo ficcional; entre o estatuto do narrador e o estatuto do autor, o que remete à teoria barthesiana da morte do autor e à total dissoluçāo entre factum e fictum. Seria então correto dizer que a mudança de paradigma entre o Realismo europeu do século XIX (para o qual a literatura se aproximava mais do documento social, atuando quase como uma narrativa histórica ou puramente antropológica, ou puramente social) e o Neo-Realismo do século XX (para o qual a História passa a ter tratamento ficcional, diluindo assim as fronteiras entre História e ficção) corresponde à mudança sofrida pela passagem do Historicismo para o Novo Historicismo, tendo o primeiro a tarefa de repre- 
sentar o passado como realmente aconteceu e o segundo consistindo em uma estrutura que aproxima os eventos reais das estruturas ficcionais?

Dentro dessa perspectiva, a obra de Euclides da Cunha torna-se uma obra de extrema importância para a história da literatura brasileira porque se torna não só a realização dessa mudança de paradigma, como também cria uma nova forma de encarar a constituição de uma literatura e nacionalidade brasileiras. Sua principal obra funda uma nova maneira de pensar a história brasileira, seus movimentos religiosos, a constituição de seu povo, e também de escrever literatura, questionando os discursos instituídos das tradições historiográfica e literária.

Assim, outro elemento surge para problematizar a discussão: a questão da verdade, o que nos leva à leitura da "Nota preliminar" de Os sertōes. Assim como outros, Luis Fernando Valente (1998, p. 45) afirma que "quando Euclides da Cunha toma da pena para escrever Os sertōes, sua intenção não é produzir uma obra ficcional". A razão disso reside no fato de o autor declarar expressamente o desejo de escrever para "futuros historiadores", situandose, portanto, dentro da tradição historiográfica, e, ainda, de buscar a verdade de todo o acontecimento histórico. Para isso, faz uso de uma citação de Taine que enfatiza o conceito de "narrador sincero" como aquele que se "irrita contra as meias verdades que são as meias falsidades". Entrega-se, portanto, à tarefa de escrever a verdade dos fatos históricos dos quais foi observador in situ, já que é enviado à guerra para validar o discurso da elite dominante e narrar a vitória do exército sobre as tropas dos vencidos sertanejos.

No entanto, a verdade parece assumir feição contrária, como se pode constatar já na "Nota preliminar" ao texto de Os sertōes. A face do narrador irônico já se deixa apresentar, de início, no paratexto assinado pelo próprio autor, levando o leitor à desconfiança com relação ao estatuto de quem escreve a nota: seria o próprio Euclides, já que sua assinatura encontra-se no fim da nota, ou estaria o autor jogando com suas diferentes máscaras narrativas, de modo a confundir autor e narrador? Um dos pontos mencionados por Valente é o fato de a imparcialidade e a objetividade, características do ponto de vista científico, ou histórico, serem "parcialmente abandonadas" em nome de uma enunciação que substitui a primeira pessoa do singular por um "nós" coletivo, que inclui o próprio autor e o associa à elite dominante responsável pelo extermínio dos sertanejos. Euclides ironiza e denuncia uma classe que o criou e o moldou, importando as idéias européias e solidificando o discurso dominante formador da mentalidade reacionária brasileira.

A nota inicia com o reconhecimento de que inicialmente a escrita do livro fora motivada pelo intuito de narrar a "história da Campanha de Canudos" pelas mãos de um enviado do governo e, portanto, como promessa de afirmação dos valores de uma elite litorânea, cientificista e positivista. 
Entretanto, o fracasso de tal empreitada se deve ao fato de que, na verdade, o tema da guerra passou a ser apenas uma "variante do assunto geral". Como poderá ser visto, é menos o conteúdo contido nos textos e mais o princípio articulador da obra que definirá a sua grandeza.

Segue a nota dizendo que o intento de tal tarefa consiste, portanto, em "esboçar palidamente embora, [...] os traços atuais mais expressivos das subraças sertanejas do Brasil" (p. 70). Ora, o leitor sabe que o narrador faz muito mais do que apenas esboçar as características do povo interiorano. Trata-se da denúncia de uma barbárie por parte das forças civilizadas e do desmonte das teorias cientificistas que pregavam a degeneração do homem por parte do cruzamento das raças. Para tanto, acredito que, já na "Nota preliminar", o narrador aparece sob sua máscara de narrador irônico, praticando a ironia fulminante que tanto marcara a escrita euclidiana. A denúncia continua apontando que os individuos do sertão são vistos como "tipos relegados às tradições evanescentes, ou extintas", já que o litoral abandonou o indivíduo do interior à sua própria sorte e destino, voltando-se para uma cultura da imitação, a mesma que saqueia e comete as atrocidades mais vulgares contra seu próprio povo. Assim, o narrador irônico começa a denunciar o "esmagamento inevitável das raças fracas pelas raças fortes".

Mais adiante, o narrador inclui a si mesmo no meio dos "mercenários inconscientes" que formam a elite esmagadora e encontram-se "mal unidos àqueles extraordinários patrícios" por conta do desconhecimento da própria nacionalidade e solo. $\hat{E}$ assim que o narrador sincero mencionado na citação de Taine, incluída na nota, aparece como aquele que deseja "sentir como bárbaro entre os bárbaros e, entre os antigos, como antigo" e pretende ser o narrador que silencia a si mesmo dando lugar à voz do outro.

Dessa forma, a "Nota preliminar" vem prefigurar a elaboração narrativa inventada por Euclides em sua obra, ao fazer uso do narrador irônico em um texto assinado pelo autor. É possível com isso dizer que a relação autornarrador é então problematizada, bem como a correspondência entre verdade e ficção, a ponto de o leitor atento começar a se perguntar onde se encontra a verdade dos fatos e em que parte se inicia o forjamento do real. Tal exemplo poderá ser comprovado no estudo do mapa do Estado da Bahia, intitulado "Esboço geológico", com referência a vários autores. Um mapa é um documento oficial que registra uma dada região geográfica com os menores detalhes significativos, de modo que o que é visto pelo observador esteja representado tal como é na carta geográfica.

Os críticos sempre foram unânimes em apontar o extraordinário conhecimento científico acumulado por Euclides, ao longo de sua vida, no estudo da geografia, da geologia e da história brasileiras e na contribuição deixada por ele em documentos oficiais encontrados no Itamaraty. É notória 
a sua participação como membro do Instituto Histórico Geográfico de São Paulo e do Centro de Ciências, Letras e Artes de Campinas e, ainda, como chefe da Comissão Brasileira de Reconhecimento do Alto Purus, que demarcou o limite do mesmo rio, nas fronteiras entre Peru e Brasil, chegando a pontos da bacia nunca antes atingidos. Nessa expedição, cujo Relatório da Comissão Mista Brasileiro-Peruana de Reconhecimento do Alto Purus foi escrito por Euclides, o autor de Os sertôes conseguiu o reconhecimento da comunidade científica, que tanto desejava, ao realizar a descoberta de um novo dado geográfico: a independência da bacia do rio Purus em relação ao rio Madre de Dios, da bacia do rio da Prata, e a proximidade das nascentes dos rios Purus, Madre de Dios e Ucaiale. José C. B. de Santana (2001, p. $172-$ 173) chama atenção para o fato de que

as considerações de Euclides da Cunha sobre o caráter divagante do rio Purus [...] mostram a sua atualização em relação às teorias hidrográficas mais respeitadas na virada do século XIX, o que permitiu a Roquete Pinto considerá-las como representando "[...] um dos mais importantes fatos geológicos adquiridos pela ciência brasileira”.

Tais informações registram a importância da atuação de Euclides da Cunha no cenário científico e cultural da época, além de apontar para a contribuição oficial dada por Euclides às noções geográficas dos estudos científicos no Brasil.

Como se sabe, por meio do artigo "A nossa vendéia", publicado em $O$ Estado de S. Paulo, no dia 14 de março de 1897, e depois na "Caderneta de Campo" e ainda no "Diário de uma expedição", Euclides pesquisou, estudou, leu, escreveu, antes mesmo de chegar a presenciar a batalha de Canudos, o que só ocorreu nos sete últimos dias da guerra. Constante fonte de informação para Euclides eram os viajantes naturalistas como Auguste de Saint-Hilaire, Carl von Martius, Johann von Spix, e cientistas brasileiros como Joaquim Caminhoá, Teodoro Sampaio, José Carlos de Carvalho, que registraram preciosos dados sobre a geografia, a botânica, a constituiçâo geológica e o clima das paragens do norte-nordeste do Brasil. Como amigo e interlocutor de grandes personagens da época, como Teodoro Sampaio, Orville Derby, Alberto Loefgren, Emílio Goeldi, entre outros, Euclides esteve sempre à frente de seu tempo, tanto como homem de ciência quanto como homem de letras. $\mathrm{Se}$, à época em que viveu e atuou, a literatura florescia em narrativas naturalistas, do lado ficcional, e em crônicas de viagem, do lado cientifico, Euclides encontra-se fora de qualquer margem definidora de gênero, elaborando uma narrativa que privilegiou a invenção de tantas máscaras narrativas quanto fossem necessárias (lição certamente legada pelo seu mestre, Machado de Assis) para explicar o complexo racial brasileiro e para 
mostrar que a batalha histórica que o Brasil inteiro assistia transcendeu o fim desejado por todos e subvertido por Euclides: naquela luta entre civilização e barbárie, os bárbaros eram os vitoriosos.

Sendo amplamente amparado pelas pesquisas científicas a que recorria sempre, aos mapas, croquis e tratados em que estudou e que ele mesmo produziu, Euclides demonstrava, ao percorrer as regiões do sertão baiano em sua expedição, um conhecimento de seu objeto de pesquisa bastante vasto. Apesar de Os sertões ter sido publicado cinco anos depois de sua viagem a Canudos, a "Caderneta de Campo" e o "Diário de uma Expediçāo" indicam o estudo prévio de uma região e observações científicas que revelam a base teórica e a formação de uma visão sólida já presentes nas idéias de um pensador brasileiro consciente de sua tarefa. Santana (2001, p. 96-97) afirma:

As anotações sobre a geologia da regiāo prosseguem no Diário e são encontradas também na sua Caderneta de Campo onde meticulosos croquis ilustram suas observaçôes sobre o relevo e onde, pela primeira vez, aparece o roteiro de um estudo a ser realizado, que resultaria em $O s$ sertōes. Várias são as anotações sobre botânica e as indicações para leituras de páginas de um livro não especificado de Humboldt [...]. Um outro aspecto significativo diz respeito ao conhecimento que Euclides da Cunha já demonstrava ter da região. Conhecimento mediado pelas leituras feitas ainda em São Paulo ou já na Bahia [...].

Isso nos leva ao próximo ponto proposto neste estudo: a avaliação do segundo paratexto, o mapa do Estado da Bahia e para isso é fundamental a leitura do primeiro capítulo de Os sertôes para que se possa comparar a descrição feita pela narrativa com os mapas utilizados por Euclides. Em "A terra", o autor aborda a geologia, o relevo, o clima e a vegetação com tal propriedade que a obra acaba ganhando reconhecimento do meio científico de então pela contribuição aos estudos geológicos da região, como aponta Santana (2001, p. 133). No entanto, o que interessa para este artigo não é levar adiante a discussão do valor científico da obra, uma vez que o foco se volta para o princípio de caráter ficcional que a articula. Deseja-se avaliar como o narrador euclidiano se comporta neste capítulo, que atua como prefiguração das narrativas desenvolvidas nos capitulos subseqüentes (" $\mathrm{O}$ homem" e "A luta"), e de que maneira a elaboração de uma realidade ficcional se sobrepõe à verdade factual e histórica.

O primeiro capítulo constitui, portanto, "a base em que o autor se apóia para compreender a ação do meio na formação das etnias e sua influência na gênese das personagens típicas" (SANTANA, 2001, p. 101). Apesar das referências explícitas a nomes como Spix e Martius, Aires de Casal, Gardner e Burton e à tradição naturalista de seu tempo, o narrador que se destaca 
parece ser o narrador viajante ou itinerante, cujo ponto de vista é impessoal, podendo-se transfigurar para expressar ora suas impressōes artísticas, ora suas impressões científicas.

No primeiro capítulo de Os sertões, aquele que mais deixa exposto a tese da literariedade da obra, a terra assume o papel de protagonista do combate travado em solo brasileiro. E é como protagonista que ela inicia o seu martírio secular. Note-se a abertura do capítulo:

O planalto central do Brasil desce, nos litorais do Sul, em escarpas inteiriças, altas e abruptas. Assoberba os mares; e desata-se em chapadões nivelados pelos visos das cordilheiras marítimas distendidas do Rio Grande a Minas. Mas ao derivar-se para as terras setentrionais diminui gradualmente de altitude, ao mesmo tempo que descamba para a costa oriental em andares, ou repetidos socalcos, que o despem da primitiva grandeza afastando-o consideravelmente para o interior. (p. 71)

A partir dos verbos de movimento que revelam ações desempenhadas pelo Planalto Central, arriscamos dizer que o solo brasileiro, representado pelo Planalto, ganha autonomia a partir de um fenômeno que aponta para a força de um solo ainda em constituição. Além disso, essa é uma terra que já se concebe como força viva, cujo animismo nāo parte da projeção do sujeito (nesse caso ela poderia ser considerada como antropomórfica, segundo alguns críticos), uma vez que o seu interior já se encontra em processo de formação. Nesse caso, se a sua superficie se encontra em transformação, como o texto revela, é somente porque o seu interior já está em processo de metamorfose contínua e, sendo assim, o narrador apenas desvela a atividade imanente de gestação interna da terra.

Após colocar o Planalto Central em movimento, o leitor segue por uma viagem rumo às paragens do sul, pela orla marítima, passando pela bacia do São Francisco, por rios e povoados até chegar por fim às paragens do norte, guiado pelo narrador itinerante. É quando chega ao norte que o narrador "estaca surpreendido" sobre um "socalco do maciço continental". Em diálogo explícito com os viajantes naturalistas que já haviam pintado e mesmo desenhado o relevo da geografia brasileira, Santana aponta o fato de Euclides tentar uma generalização a partir de dados encontrados em fontes diversas, acabando por produzir uma seqüência geográfica que nâo corresponde imediatamente a um cotejo direto com qualquer mapa geográfico brasileiro.

Segundo Aroldo de Azevedo (apud SANTANA, 2001, p. 104), Euclides da Cunha incorre em um brutal erro geográfico ao confundir o planalto brasileiro em sua totalidade com o Planalto Central (que seria apenas uma de suas partes), cujos limites estariam completamente fora de escala. E o 
crítico chega a qualificar o esboço geológico de Euclides de "obsoleto" e sugere que "nas próximas ediçôes do livro se corte a palavra 'central"' (SANTANA, 2001, p. 104); alega também que não haveria os "recifes" apontados pelo autor na costa fluminense, e que duvidava que Teodoro Sampaio e Orville Derby constantes interlocutores de Euclides e ouvintes de Os sertōes em processo de escrita - aprovassem tais descrições.

Assim, duas questões são levantadas por Santana (2001, p. 108):

Por que Euclides da Cunha, conhecendo os trabalhos citados que tratam das questōes do planalto brasileiro [...] denominou de "planalto central" a unidade que descreve e ainda, se incorreu em "erro geográfico", por que não o corrigiu posteriormente, se uma de suas cadernetas de anotaçôes tem quatro páginas e meia de transcrições extraídas do relatório do geólogo da Comissão Exploradora do Planalto Central do Brasil, e se a preocupação com a correção das edições de Os sertōes é um dos traços sempre lembrados da personalidade de Euclides da Cunha?

A resposta oferecida pelo pesquisador se apóia, em resumo, na explicação oferecida por Flora Sussekind, que aponta para a necessidade que a literatura encontra em fundar uma nova geografia a partir das narrativas dos naturalistas viajantes, tão apreciadas por Euclides. De certo modo a geografia do território brasileiro fundada por Euclides da Cunha deseja expor a visão de que esse território, a constituição de sua nacionalidade e de seu povo, a elaboração de uma língua e cultura originariamente brasileiras (e os modernistas precisamente vinte anos depois da publicação de Os sertôes mostrarão isso), não estão constituídos, mas ainda em estágio primário de formação.

A partir da leitura do texto euclidiano, nota-se que o narrador retorna ao passado pré-histórico para relatar inclusive a formação do continente americano como um todo, isto é, de um território e nação muito mais vastos do que o território brasileiro, que inclui a América do Sul, a Central e a do Norte, a fim de denunciar o seu processo de formação contínua, como pode ser observado no seguinte excerto:

Não existiam os Andes, o Amazonas, largo canal entre altiplanuras das Guianas e as do continente, separava-as, ilhadas. Para as bandas do sul o maciço de Goiás - o mais antigo do mundo - segundo a dedução de Gerber, o de Minas e parte do Planalto Paulista, onde fulgurava, em plena atividade, o vulcão de Caldas, constituiam o núcleo do continente futuro...

Porque se operava lentamente uma sublevação geral: as massas graniticas alteavam-se ao norte arrastando o conjunto geral das terras numa rotação vagarosa em torno de um eixo [...]. Simultaneamente, ao abrir-se a época terciária, se realiza o fato prodigioso do alevantamento dos Andes; novas terras afloram nas águas: tranca-se, num extremo, o canal amazônico, 
transmudando-se no maior dos rios; ampliam-se os arquipélagos esparsos, e ganglionam-se em istmos, e fundem-se; arredondam-se, maiores, os contornos das costas; e integra-se lentamente, a América. (p. 93-94)

Parece claro que todo o ambiente de retorno a um passado das origens aponta para a irrupção desse passado em um presente originário. Em outras palavras, é o presente que funda o novo tempo, a nova história. Assim, o presente não regressa a uma origem, ele é a própria origem porque funda uma nova temporalidade. Se se observar a maneira como o planalto brasileiro se movimenta, é possível notar que seu relevo vai se modificando ao passo que o narrador se desloca. O "traço contínuo e dominante das montanhas" (p. 71) de repente se transforma em um "aparelho litoral revolto" (p. 72) e a terra "enverga-se" sobre si mesma, desarticulando-se, corroendo-se, escancelando-se, repartindo-se e desagregando-se, de modo a evidenciar o "conflito secular" que terra e mar sofrem. A desagregação só acontece porque é seguida de uma mudança de ângulo e de paisagem, "até que [...] o olhar [...] se dilata em cheio para o ocidente, mergulhando na terra amplíssima lentamente emergindo num ondear longínquo de chapadas..." (p. 72). Assim, o narrador define o drama vivido pela terra como prefiguração do drama vivido pelo homem. A mesma força de constituição e de resistência vivenciada pela terra será experimentada pelo sertanejo.

Pode-se constatar que o martírio encenado pela terra na primeira parte da obra aponta para o movimento autoformativo contínuo que se desenrola na constituição do solo brasileiro. Esse processo será o mesmo experimentado pelo homem no curso de sua formação. Homem e terra implicam-se mutuamente e atuam um sobre o outro, e a mesma força interna que compóe a terra comporá o homem. Assim, na segunda e na terceira partes da obra, constatar-se-á que a terra se tornará a aliada do homem e sua co-parceira na luta contra o exército. Dessa forma, a crença de que o homem é produto do meio é apenas parcialmente válida nas obras de Euclides da Cunha. Não há determinismo porque a relaçâo entre solo e homem é de reciprocidade e parceria.

O segundo capítulo de Os sertōes, intitulado "O homem", inicia-se tratando da complexidade do problema etnológico do Brasil, a partir da afirmação de que "a gênesis das raças mestiças do Brasil é um problema que por muito tempo ainda desafiará o esforço dos melhores espiritos. Está apenas delineado" (p. 151). Com essa afirmação, Euclides iniciará sua exposição sobre a composiçâo do povo brasileiro, formado do entrelaçamento complexo de três elementos, o que the confere um caráter de raça ainda em constituição. E o sertanejo é o representante dessa mistura. Após apontar a complexidade etnológica brasileira, o narrador passa a falar da complexidade climática do território brasileiro em um subcapítulo intitulado 
"Variabilidade do meio físico". Nele, chega à seguinte idéia: se o clima é a "tradução fisiológica de uma condição geográfica" (p. 157) e se a estrutura climática brasileira apresenta um "contraste empolgante" (p. 159), entendese que o tal contraste, muitas vezes colocado como antítese, presente também na flora, na fauna e no relevo, é o mesmo encontrado entre o sertão $\mathrm{e}$ a costa, bem como na formação de povo e raça brasileiros. Assim, o narrador conclui sua tese: "A nossa história traduz notavelmente estas modalidades mesológicas” (p. 168).

Nos subcapítulos seguintes, após explicitar sua convicção de que o "o meio não forma as raças" (p. 174), o narrador prossegue delineando a formação das "sub-raças" brasileiras, apresentando a gênesis do mulato e dos jagunços, a distinção entre os cruzamentos realizados no sertão e aqueles realizados no litoral para, em seguida, abrir o que chama de "um parêntesis irritante" (p. 199). Nele, uma vez mais, o narrador muda sua máscara narrativa e passa a assumir as vozes dominantes das crenças evolucionistas do litoral. E é nesse parêntesis que o narrador trata do mestiço como um "desequilibrado", um "retrocesso", um "decaído", um "intruso", "sem caracteres próprios", "frágil", "inconstante" e, é claro, "inferior". Evidentemente, o narrador aqui atua como a voz delatora do distanciamento e do grau de negligência que o litoral tem com o interior. $\mathrm{E}$ a voz entoada pelo refletor dramático só tem espaço porque, logo em seguida, a narrativa se abre para a voz do historiador irônico que, pela estratégia de contraste que mantém do início ao fim, apresenta o mestiço como "uma raça forte" (p. 202).

Nesse momento, o narrador denuncia que o comportamento instável e revolto do mestiço revela apenas o esforço feito para eliminar exatamente as forças que lhe dificultam a vida em meio ao descaso com que o litoral o trata. E para vencer, eles guerreiam. Entretanto, a ironia fria e metálica revela: "a raça forte não destrói a fraca pelas armas, esmaga-a pela civilização" (p. 203). E o contraste aparece - o sertanejo, isto é, o povo brasileiro, não é um degenerado: "É antes de tudo um forte. Não tem o raquitismo exaustivo dos mestiços neurastênicos do litoral" (p. 207). E se sua aparência externa, tal como a da vegetação da caatinga, pode parecer desgraciosa, desengonçada ou torta, o sertanejo se projeta, "gigante e sinuoso", na imagem do "HérculesQuasímodo" do sertão. Tal como a caatinga, em seu conceito humboldtiano de planta social, que se transforma nos "verões queimosos" e nos "invernos torrenciais" e alia-se aos sertanejos encenando a batalha contra o exército nacional, da mesma forma se transforma o sertanejo, projetando a grandeza de sua humanidade: "Naquela organização combalida operam-se, em segundos, transmutações completas [...] e da figura vulgar do tabaréu canhestro, reponta, inesperadamente, o aspecto dominador de um titã acobreado e potente [...]" (p. 208). 
Para avaliar Conselheiro, exemplo da complexidade étnico-socialreligiosa presente no Brasil, o narrador aparece como o investigador dialético, e o exemplo histórico que utiliza para tal é a revolta de Canudos. O investigador dialético parte de um ponto de vista não fixo já que, para compreender o fenômeno descrito, é necessário não se deixar projetar num esquema conceitual determinado, pois o que vê lhe causa profundo impacto. Adotando uma visão multiperspectivada, o investigador pode se abrir para a construção de um saber não restringido pelo discurso do conhecimento científico com relação à investigação da constituição de um povo como o brasileiro. Esse povo apresenta-se por si mesmo como um enigma, pelo seu entrecruzamento étnico. Assim, o narrador traz ao debate dialético a visão dos seus predecessores e apresenta as visões científicas, por vezes mal compreendidas, já que dâo voz às teorias racistas da época. $\mathrm{O}$ narrador então assume a posição de mediador crítico das diferentes visões e teorias antropológicas e sociológicas que tentam explicar o fenômeno.

No entanto, se as classificações e interpretações feitas por Euclides revelam as patologias de um "tipo" como Conselheiro, elas só o fazem propositalmente de maneira que o discurso dominante das autoridades e do litoral ficasse exposto e pudesse ser desmascarado pelo principal recurso da pena euclidiana: a ironia. Ao longo de todo o texto, e especificamente nos capítulos II e III, o autor constrói sua narrativa fazendo uso do multiperspectivismo narrativo, de modo que os discursos da Antropologia, da Sociologia, das Ciências Naturais anunciem seus veredictos sobre o réu Antonio Vicente Mendes Maciel, mas não sem antes passarem pela língua feroz de Euclides. Entre tantas denominaçōes e classificações, as teorias sobre Conselheiro apresentam-no como um sectário do gnosticismo, tornado bruto e violento pelo meio e pelas adversidades sofridas e contadas no início do capítulo, em um ponto de vista que privilegia a teoria romântica rousseauniana de que o meio modifica e corrompe o indivíduo. Não é à toa que à página 265, em seção intitulada "Primeiros reveses", o autor busque uma explicação racional para a transformação de caráter de Conselheiro:

Dai sua existência dramática. [...] A partir de 1858 todos os seus atos denotam uma transformação de caráter. Perde os hábitos sedentários. [...] De repente, surge-lhe revés violento. $\mathrm{O}$ plano inclinado daquela vida em declive termina, de golpe, em queda formidável. Foge-lhe a mulher, em Ipu, raptada por um policial. Foi o desfecho. Fulminado de vergonha, o infeliz procura o recesso dos sertões, paragens desconhecidas, onde não Ihe saibam o nome; [...] Desce para o sul do Ceará. Ao passar em Paus Brancos, [...] fere com impeto de alucinado, à noite, um parente, que o hospedara. Fazem-se breves inquiriçōes policiais, tolhidas logo pela própria vítima reconhecendo a não culpabilidade do agressor. Salva-se da prisão. 
Prossegue depois para o sul, à toa, na direção do Crato. E desaparece..." (p. 265-166)

Note-se a descrição por vezes jornalística, por vezes cinematográfica, que a linguagem assume, revelando o jogo elaborado do narrador para que o leitor seja convencido pela narrativa a seguir um olhar de júri, ora de absolvição, ora de condenação do réu. Recupera-se assim o caráter lúdico de uma narrativa construída para guiar e dissimular o leitor, de modo que, junto à ironia, uma outra característica própria da linguagem euclidiana irrompa de ponta a ponta da obra: a encenação. Berthold Zilly (1998) aponta para o tratamento pictórico e dramático dado à guerra e à História, que surgem como painel em que é encenada uma grande tragédia, na qual o único herói é o sertanejo, pela resistência com que enfrenta e vence o exército inimigo. "Trata-se, portanto, de um drama não apenas metafórico, mas de certa forma real, que expressa exemplarmente a tendência euclidiana de apresentar a história como peça de teatro" (ZiLLY, 1998, p. 23).

Os personagens de Os sertões são apresentados como dramatis personae que encenam esse "emocionante drama da nossa história", como é descrita a batalha de Canudos por Euclides. Se, inicialmente, a terra, o solo, a flora, a fauna, o clima, os ventos, as bacias e rios - toda a geografia, com o Planalto Central como protagonista do primeiro ato ("A terra") - revelam-se como os principais agentes que elencam e preparam o palco para o teatro da guerra a se desenrolar nas paragens brasileiras, logo em seguida entra em cena o homem, representado nas figuras dos sertanejos, de Conselheiro e dos tenentes, generais e comandantes do exército: Frederico Sólon, Febrônio de Brito, Moreira César, Pedro Nunes Tamarindo, enfim o homem brasileiro.

$\hat{\mathrm{E}}$ assim que todos os personagens históricos que, na narrativa de Euclides da Cunha, ganham novos e diferentes traços, junto à natureza do relevo brasileiro, surgem como personagens fictícios dentro de uma obra que remodela os fatos e reinventa o real porque se deseja e se apresenta como obra instauradora de uma nova modalidade de expressão e, portanto, de um novo universo.

\section{O BRUXO DO CONTESTADO: NEO-REALISMO NA FICÇẢO BRASILEIRA CONTEMPORÁNEA}

O bruxo do Contestado, doravante O bruxo, publicado em 1996 (94 anos depois de Os sertôes), surge para a crítica brasileira como a primeira parte da trilogia catarinense que remete à origem da terra natal e ao reencontro cultural como reconstrução memorialista escrita por Godofredo de Oliveira Neto, seguida logo depois de suas outras partes: Pedaço de Santo, de 1997, e Marcelino Nambrá, o Manumisso, de 2003. As três obras revelam um 
conteúdo marcadamente político, voltado para a esfera social de um coletivo, concebendo a experiência estética como fenômeno ético-social que interfere na transformação individual do homem. Como afirma Oliveira Neto em entrevista concedida ao jornal O Catarina! e em explícita referência ao impacto de Euclides da Cunha em sua própria produção literária: "Antes dele [de O bruxo], houve Canudos e Os sertões." Além da menção direta, nota-se a influência e o diálogo marcantes da obra euclidiana em $O$ bruxo por parte do tema a ser tratado - a guerra do Contestado, com todas as implicaçôes religiosas, políticas e territoriais que a aproximam da guerra de Canudos - e do intertexto euclidiano, por vezes em citaçôes diretas, por outras em referências indiretas.

Assim sendo, a mesma preocupação com a correspondência entre História e ficção verificada na obra euclidiana é abordada no romance de Oliveira Neto. Se Euclides da Cunha levanta a questão, ainda em 1902, O bruxo a problematiza ainda mais ao criar uma narradora que se confunde com o autor. E, ainda, se em Os sertōes, a consciência autoral tenta ser neutra, concedendo espaço às "várias versôes de si próprio" (BоoTH, 1980, p. 89), no decorrer do texto e dos capítulos, em $\mathrm{O}$ bruxo a estrutura se complexifica ainda mais pelo fato de o romance se dividir em dois planos temporais: o das cartas escritas por Tecla, a narradora, e o do romance. Para ambos os autores, a falsa questão sobre o estatuto ficcional ou jornalístico/histórico da obra continua a mesma, porque pouco importa se há exageros, inverdades ou equívocos: por mais que se tente, o real jamais poderá ser tocado em sua plenitude, e o grande compromisso da arte é o de se desvincular das representações forjadas pelos discursos e inventar a sua própria verdade.

Euclides da Cunha, no entanto, por participar da comunidade científica de sua época, por ser um homem de fato interessado no discurso da ciência e em sua prática, por fazer parte de uma tradição literária muito próxima e marcada pelo olhar dos viajantes naturalistas e, ainda, pelo fato de ter sido testemunha do fato histórico de que fala (apesar de só ter chegado nos últimos dias da guerra), acaba propositadamente criando uma obra muito contaminada pelo discurso científico. Oliveira Neto, por outro lado, apesar da advertência da "Nota aos leitores" e do "Esclarecimento" ao fim do romance, nos quais chama atenção para a presença do conteúdo histórico, não busca um consórcio entre ciência e arte, como faz Euclides, seguindo mais explicitamente o caminho traçado por Graciliano Ramos em Säo Bernardo, no qual a presença do discurso literário domina por inteiro as preocupaçōes do autor.

E é na mesma trajetória de Graciliano Ramos que o texto de Oliveira Neto se desenrola. Para esquadrinhar o conflito que envolve a relação entre a ficção e o real, a leitura do texto será feita a partir dos seus paratextos mais significativos. A estrutura narrativa de $\mathrm{O}$ bruxo é composta das três epígrafes 
que se referem constantemente ao texto ficcional por inteiro, seguidas pela "Nota aos leitores" que, junto ao "Esclarecimento" localizado no fim do romance, amplia o caráter de ambigüidade com relação à autoria da narrativa e, por fim, pelas cartas escritas por Tecla, em número de sete intercaladas no corpo do texto. Apesar de não constituírem parte da narrativa sobre $O$ bruxo em si, as cartas fazem parte de toda a construção ficcional da obra, bem como os outros paratextos. Ao avaliar ainda o diálogo intertextual com autores da tradição literária brasileira, este texto busca apontar como o paratexto e o intertexto auxiliam na construção metanarrativa da obra.

Se a idéia de paratextualidade vem complementar o estudo da obra ficcional por se constituir uma forma de texto fora do corpus ficcional - e que remete, ao mesmo tempo, ao texto e aos outros paratextos, num acréscimo de sentido e conteúdo -, é também ela que contribui para o efeito de ambigüidade entre real e ficcional, já que o paratexto não é, na maior parte dos casos, uma criação ficcional. Entretanto, em O bruxo, pode-se notar como a "Nota aos leitores", o "Esclarecimento" e, principalmente, as cartas acabam se tornando construções ficcionais criadas pelo autor para aumentar o grau de dúvida e gerar confusão no leitor quanto à veracidade e à neutralidade do que é dito. Para isso, a noção de autor implícito, proposta por Wayne Booth, servirá como ponto de partida para este estudo. Segundo o teórico, "enquanto escreve, o autor não cria simplesmente um 'homem em geral', impessoal, ideal, mas sim uma versão implícita de si próprio" (Воотн, 1980, p. 88), podendo variar seu ponto de vista em quantas posiçōes lhe convier.

$\mathrm{Se}$, logo de início, se interpretar o conteúdo das epígrafes que introduzem a obra, pode-se verificar que todas elas estão conectadas por uma idéia comum: a de que a natureza humana, bem como a do discurso literário, é composta por elementos tão múltiplos e díspares que se combinam entre si apontando as contradições da realidade e expondo os dilemas e complexificaçōes presentes no interior de um indivíduo e de uma sociedade. A literatura, a partir da manipulação e do trabalho com a linguagem, pode assim desfazer e alterar paradigmas ao trabalhar com representações e valores construídos pela cultura de uma sociedade e pela própria tradição literária.

Nầo à toa, as epigrafes são retomadas ao longo do romance pela própria fala dos personagens, sempre tendo como referência a figura de Gerd, personagem ambíguo e fantasmagórico, que permeia a fronteira do humano e do monstruoso. Gerd, bem como a Guerra do Contestado, é reflexo das contradiçōes de uma sociedade que constrói as suas próprias aberraçôes. A descrição da alteração da mandioca-mansa em mandioca-brava que, repentinamente, sem razão ou explicação, "vai em amargando, de tanto em tanto, de si mesma toma peçonha" chegando a matar, aponta para a violência encontrada na descrição do rio à página 138 , como prefiguração da alteração sofrida 
também pelo homem: "O rio dócil, refrescante, fonte de vida, tornava-se subitamente, um inimigo impiedoso, voraz e assassino". A oração, tâo devedora do estilo euclidiano, aponta para o transmudamento repentino da natureza (que constituirá uma metáfora para o transmudamento do homem figurado pela personagem de Gerd). E, ainda, à página 181 , a mesma referência reaparece, agora em discurso direto da personagem Antônia sobre o estranho comportamento de Rosa: "Ela discorreu, ainda por mais algum tempo, sobre as alteraçōes do comportamento humano e comparou-as a elementos da natureza: 'É como a mandioca. Tem uma que mata e outra que engorda. $\mathrm{E}$ a mesma terra deu as duas"'. Parece, assim, que o mais importante é o fato de que o conteúdo das epígrafes, colocado por vezes na boca dos personagens em discurso direto e, por outras, no discurso do narrador, gera ambigüidade e desconfiança acerca de sua autoria. O leitor, peça vital na construção do significado do texto, não sabe se a voz no texto é a dos intertextos, a do narrador ou a do personagem, $e o$ autor aumenta assim o ambiente de tensão entre real e ficcional.

Em seguida, o leitor depara-se com o tom objetivo e neutro da "Nota aos leitores", na qual o autor apresenta a simulação de elementos documentais com o objetivo de confundir o leitor inexperiente. Trata-se de uma dupla simulação, já que se refere não só a fatos que jamais existiram, como o "caderno encontrado em um palacete em demolição no centro da cidade de Sâo Paulo", ou o casarāo e as lojas comerciais da família Jonhasky, mas também aos personagens que, mais tarde, farão parte do romance escrito por Tecla, alter ego do autor e personagem fictício. Assim, Oliveira Neto promove estranheza e dúvida com seu ato de falsificação da verdade, na medida em que o "documento" forjado trata de elementos ficcionais como Tecla e sua família, bem como o manuscrito do romance. A simulação criada contribui para o engano do leitor não iniciado, levando-o a crer que tal nota não passa de uma advertência do autor, quando na realidade trata-se de uma estratégia ficcional utilizada, na qual a voz da nota esconde a voz da narradora, que se torna personagem de suas próprias cartas. Assim, as fronteiras entre documento e obra ficcional se diluem até o completo apagamento no fim do romance.

Em seguida, o leitor depara-se com o texto integral, divido em dois planos temporais diferentes: o das cartas, que intercala a narrativa e remete ao momento histórico de abertura política e de intensa agitação nacional da década de 1980, e o outro referente à saga da família dos Rünnel, que se passa aproximadamente nos anos 40 . São, portanto, dois planos temporais distintos interligados pela história e pela literatura, já que é Tecla (personagem fictício) quem decide narrar a história de personagens reais (do ponto de vista de Tecla) dentro de uma narrativa ficcional (do ponto de vista do autor). 
Trata-se assim de uma narrativa que privilegia a técnica de escrita em mise en abyme, expressão empregada por André Gide em 1893, que consiste em inserir uma obra dentro da obra, como se uma espelhasse a outra, em efeito de reduplicação. Forma de expressão privilegiada por autores contemporâneos, a mise en abyme problematiza a relação entre autor, obra e leitor e, no caso de $\mathrm{O}$ bruxo, revela a estrutura de uma narrativa que narra histórias dentro de outra narrativa criada a partir de narrativas históricas. As cartas de Tecla, como toda narrativa epistolar, são escritas em primeira pessoa e, nelas, encontra-se a descrição metaficcional da criação do livro $O$ bruxo do Contestado, cuja autora é Tecla, alter ego do autor. Assim, elabora-se uma narrativa interrompida sete vezes pela leitura das cartas em uma fração de tempo e lugar estratégicos no texto. O texto sobre a família Rünnel é narrado em terceira pessoa. Se, no romance de Oliveira Neto, os acontecimentos são transmitidos pelo texto ficcional, há ainda o confronto contínuo com textos da tradição literária, que atuam como metatextos fornecendo esclarecimentos sobre a construção da obra.

Assim como Graciliano Ramos fez em São Bernardo, a personagem Tecla, autora e narradora ao mesmo tempo, inicia e retoma inúmeras vezes a escrita de seu romance e dá até notícias e detalhes do processo de construção da obra, como no seguinte excerto: "Hesitei muito em dois pontos. Devia dar um título ao manuscrito. Não tem como não dar. E também fiquei na dúvida se atribuía aos membros da minha familia nomes fictícios. Optei, finalmente, por deixar os verdadeiros, inclusive o meu, Tecla" (p. 13). Isso remete a duas noções diferentes do romance em questão: aquele escrito por Tecla, que inclui apenas a narrativa dos Rünnel e aquele escrito por Oliveira Neto, que problematiza a noção de autoria e do narrador ficcional, incluindo todos os paratextos. Aos olhos do leitor iniciante parece que a "Nota aos leitores” é de autoria de Oliveira Neto e que a narrativa que se segue é o resultado do episódio descrito na "Nota". Portanto, o autor apenas estaria relatando o acontecimento e publicando os documentos encontrados sem alterá-los.

No entanto, com um pouco mais de leitura, descobre-se que não só a história foi toda forjada pelo autor, bem como as cartas e todas as advertências. Com isso, confuso e duvidoso, o leitor começa a se perguntar o que é fato e o que é ficção. Compreende-se então que a imparcialidade e a neutralidade do autor já não se sustentam, e a ficção já não é uma criação unilateral e tampouco representa uma verdade única, apesar de aparecer sob o signo de uma única identidade autoral. Tecla se confunde com Oliveira Neto, se bem que ele usou de todas as técnicas narrativas possíveis para comprovar sua autenticidade. Assim, a tarefa da construção da narrativa não é realizada por um único autor, mas se divide entre o autor e seu duplo (que é ele próprio) e, 
ainda, entre estes e o leitor. Pode-se afirmar com isso que a ficção pode até mesmo mascarar o real, mas o real, por sua vez, oculta a ficção. A obra é real, mas o que está dentro dela é ficção. O discurso literário acaba envenenando a si mesmo e se tornando uma ameaça a si e à sua integridade enquanto verdade, já que, ao depender da imaginação e da interpretaçāo do interlocutor, essa mesma verdade pode assumir faces ambíguas.

Em diálogo intertextual com a tradição literária ocidental, Tecla afirma: "Para a preparação de um dos meus cursos na Dinamarca, recorri ao Fedro, de Platão, onde, no diálogo sobre a retórica, a escrita é assimilada a um perigoso veneno que mata a integridade da palavra" (p. 63). Está por trás dessa exposição o limiar que separa o falso do verdadeiro e, ainda, a ambigüidade do termo pharmakon, o veneno a que se refere o texto platônico e que, em suas várias acepçôes, pode significar também remédio ou filtro. A escrita, se entendida como referência ao discurso de Lísias no Fedro, é um veneno porque mata a experiência viva e vivificante proporcionada pela palavra, mas a palavra, se entendida como referência ao processo filosófico de autoconhecimento proporcionado e aplicado por Sócrates, é o remédio para o engrandecimento da alma. Assim, portanto, a palavra pode manifestar sua natureza maléfica ou benéfica, como a mandioca, como as águas do rio, segundo as proposiçōes do romance de Oliveira Neto. O pharmakon é sempre o caminho da dupla via, ou pelo menos da via que faz sair dos caminhos costumeiros e se abre para a multiplicação dos horizontes. O êxodo que se estabelece a partir dessa via aberta é interno do homem, que o faz sair de si mesmo (nesse caso autor, leitor e personagem são envolvidos na trama), e ao mesmo tempo externo a uma cultura e tradição que buscam a ruptura, atributo próprio das artes e da literatura. A escritura é, portanto, o descaminho.

Mas é Derrida (2005, p. 18) quem oferece o melhor esclarecimento: não nos é possível ou talvez permitido descobrir "em nós mesmos" e "por nós mesmos" a verdade da escritura, uma vez que ela é objeto de uma história (o mito) repetida infinitamente pelo homem sem que ele saiba. Próximo a esse limiar está Umberto Eco (1985), que adverte: o escritor contemporâneo, para não dizer pós-moderno, não pode se furtar a reconhecer que traz em sua escritura a lembrança da cultura de que está embebida, isto é, de que a escritura falará sempre de uma história já contada, sem que isso impeça o escritor de engendrar um universo tão novo, tâo original que não tenha precedentes, mas que não deixa de revisitar constantemente o passado.

$\mathrm{Na}$ carta 3, apresentam-se os bastidores da narrativa. Tecla comenta a escrita de $O$ bruxo como parte de suas atividades paralelas, mas o aspecto metatextual da narrativa está fora do alcance do leitor e portanto resta apenas o texto pronto. Pode-se dizer, com isso, que a referência ao processo de composição da narrativa se esvaece somente para confundir ainda mais o 
leitor. Assim, cabe questionar a narrativa: Tecla é personagem ficcional e assina como tal ou é autora do texto? Inverte-se o ponto de vista e a realidade passa a ser vista como ficção. É por meio das cartas de Tecla que se torna cada vez mais claro o caráter de duplicidade da autoria. Nas interlocuções metatextuais de Tecla, o leitor fica a par de dados biográficos do autor e de como eles se mesclam com a vida ficcional de seu alter ego. O real começa a ser modificado pelo ficcional. E, ao denunciar o forjamento da escrita ficcional e a participação do leitor, única parte real do pacto, a narradora funde sua voz com a voz do autor e já então não se sabe quem fala, mas a mensagem é bem clara: "a escrita vem travestida, é enganadora e [...] ela pode matar o sentido da palavra” (p. 63). Além disso, o recurso de jogar o manuscrito fora e a referência a Graciliano Ramos - o mesmo ato foi realizado pelo personagem ficcional Paulo Honório - coloca Tecla no mesmo plano do narrador e autor da narrativa de São Bernardo, intensificando ainda mais o apagamento da fronteira entre real e ficcional. Assim, o que se inventa já não é mais o ficcional, mas o real através de um processo de invenção e modificação a partir de fatos reais. Tecla torna-se tão autora quanto o autor, e acaba assumindo o seu discurso e o verdadeiro autor torna-se apenas uma personagem.

Na carta 4, uma vez mais retorna-se à discussão entre a possibilidade de Tecla se apropriar do texto do autor e de se tornar ela própria a autora da obra. Quando diz: "Releio e corrijo O bruxo do Contestado, que, de alguma maneira, serão as minhas memórias" (p. 99), o leitor se pergunta de quem é a voz do texto, se da narradora Tecla, refletorizada pelo autor, ou se dele mesmo, já que, como declara Oliveira Neto em entrevista, " $[. .$.$] nos três textos$ (a trilogia catarinense) está exposto grande parte do processo civilizatório e identitário do meu Estado."

Já a carta 5 utiliza, dentro de um metatexto (a carta) o discurso de outro metatexto: o cinematográfico. Ao mencionar os três filmes a que assistiu no cinema (e a escolha cuidadosa dos filmes em questão revela o olhar atento do autor) - Blow up, The devils e Vidas secas - notam-se, a partir do discurso de Tecla, os questionamentos do próprio autor: a descoberta do real por meio da câmera fotográfica e não pelo olhar da personagem denuncia a multiplicidade do real e a impossibilidade de definiçāo da verdade por meio de um discurso único. Encontrar a verdade de si mesmo requer o encontro com o outro, assim como a escrita de um texto passa pela escrita de uma tradição, assim como a experiência histórica de um passado de conflitos deve passar também pela verdade dos vencidos, assim como a escrita do universal (a guerra) deve passar pela escrita do privado (a família). A guerra vive no destino da família e, assim como o Contestado se dissolveu, da mesma forma se dissolverá a familia na narrativa de O bruxo - o fim do romance se aproxima 
do fim da vida de Tecla. Ao resgatar a memória dessa guerra histórica, o autor acaba por esgarçá-la ao máximo.

É na última carta, entretanto, que se revelam as palavras mais autoexplicativas com o retorno do tema das epígrafes pela boca da própria Tecla: "Acho que temos mesmo Deus e o Diabo dentro de nós. Um dia sai um, outro dia sai o outro. Vai de Dom Quixote a Sancho Pança, não esqueço a voz de Drummond dizendo: "Uma coisa são sempre duas: a coisa mesma e a imagem dela. Kant" (p. 202). Seria possível dizer: Euclides. Rosa. Clarice. Godofredo. Mas que importa tudo isso? A literatura continuará usurpando o real por meio da linguagem e escrevendo histórias reais, fantasias, sonhos e visões.

Saindo do paratexto, passando para a narrativa em si e seguindo o foco principal deste artigo, isto é, a relação entre História e ficção, o foco se concentrará apenas no capítulo 15 de $O$ bruxo por acreditar que nele está contida a questão do tema proposto. O capítulo inicia com uma palestra a ser apresentada por Elsa sobre o Contestado e, não despropositadamente, termina com uma paráfrase de Euclides.

Sua palestra recupera novamente a técnica de mise en abyme já que, em discurso indireto livre, Elsa narra longamente a história da guerra do Contestado, servindo como personagem refletor que narra a partir de um ponto de vista, entre tantos. Mas, nesse ponto, o discurso indireto livre da personagem confunde o leitor e deixa espaço para que o autor e suas máscaras de autor implícito despontem no texto. Ao optar por não fazer uso do monólogo direto, a narrativa produz um efeito de semelhança da voz do discurso do narrador com a voz de qualquer sujeito. Assim, um discurso se apropria de outro discurso.

Após dissertar sobre a construção das ferrovias no sul, a imigração de operários e o conseqüente desequilibrio econômico e social causado pelo fim das construções, o alheamento por parte do governo e a eclosão do conflito, observa-se um contraponto entre o amplo e o restrito. Elsa é a voz que expõe o caráter público da História e as interrupções feitas pela audiência introduzem o aspecto privado dos acontecimentos, como se segue:

Dieter interveio e informou que um membro da familia Wolland, de Diamante, lutara e morrera no Contestado ao lado dos fiéis.

- Era chamado de o Alemãozinho, e foi nomeado comandante por Maria Rosa, uma das virgens. [...] Ainda segundo o sobrinho do Alemãozinho, tentou-se passar uma idéia de guerra por princípios religiosos e políticos, mas no fundo era uma simples disputa de poder local. (p. 123)

Ao longo do relato proferido, constrói-se um discurso que busca desvincular a questão messiânica da disputa pelo poder local, dando assim duas 
direções para a explicação da guerra: uma de sentido político e social, pela igualdade e melhores condiçôes para os despossuídos, e outra de sentido religioso e messiânico. A utilização do discurso irônico novamente se assemelha ao estilo euclidiano de denúncia. A narrativa vai se desenvolvendo em direção à criação de uma utopia que vira mito. A definiçāo da escritura: repetir sem saber.

$\mathrm{O}$ fato de a personagem não introduzir um discurso direto abre caminho para que os ouvintes interfiram, mas a quem eles representam? As interferências, ou máscaras narrativas que apresentam falas variadas, são propositais e se, em Os sertões, tais interferências contribuem para a criação de um ambiente altamente irônico em que a verdade é contestada, é possível afirmar que esse é também um efeito encontrado na narrativa de $O$ bruxo, de maneira a refutar a veracidade da representação.

Apesar de ser "contestado" pela fala de outros personagens, o discurso elaborado por Elsa conduz a uma realidade ficcional inventada, portanto, os fatos apresentados não conduzem a uma verdade factual. Assim, o autor forja uma verdade a partir da manipulação do real com a intenção de criar uma atmosfera dialógica e não-autoritária, repetindo o mesmo gesto de Euclides da Cunha em Os sertōes.

Cada informaçăo acrescenta um dado novo, e a seleção de aspectos combinados é feita de modo a constituir um panorama de totalidade da explicação do tema; no entanto, é desfeita a partir das outras personagens que aparecem como vozes, em contraste particular com relação à visão do Contestado. A realidade é, assim, construída a partir do multiperspectivismo narrativo.

O Contestado passa a ser visto como disputa entre mercenários, o que não acontece em Canudos, e é apresentado pela narrativa a partir da ênfase em seu aspecto político, suspendendo assim o caráter messiânico contido no episódio. Essa construçāo tem por trás o discurso do autor que trata do refluxo do passado por meio da história da guerra. Dessa forma, a presença do fato histórico na memória popular morre com a família de Gerd, mas ressurge com o movimento de resistência que se estende até a década de 1980 no panorama político brasileiro, do qual Tecla é personagem. Portanto, o autor faz da família de Gerd o núcleo dramático, por trás do qual se narra a história da Guerra do Contestado. Observa-se, assim, ao longo da obra, o equilíbrio entre uma atitude ampla do público (o geral, tendo a guerra como representação) e a observação do particular, da vida privada (tendo como exemplo a história da familia dos Rünnel).

Gerd, por sua vez, é a própria contradição do Contestado por ser um enigma. Se o personagem é apresentado como monstro ao longo do romance, as suas crises e tentativas de bondade e compreensão para com Rosa apontam 
apenas para a ambigüidade de seu caráter. Com a filha e com a esposa, e mais tarde sozinho, Gerd é construído pelo narrador em sua dualidade humana, a mesma refletida na natureza pela mandioca e pelas águas do rio. O Contestado é a grande metáfora de que Gerd é metonímia. O homem, personagem histórico ou ficcional, é o mesmo, seja na História de ontem ou na literatura do hoje, e o escritor é o porta-voz das contradições geradas pela psique humana e tem o dever de perturbar a ordem estabelecida. Em entrevista registrada no livro Papos contemporâneos, Godofredo de Oliveira Neto chama a atenção para o fato de a escritura ser perturbadora porque suas instâncias narradoras estão inseridas na história. $\mathrm{O}$ texto é

o enfrentamento entre o ser humano e o bicho que tem dentro de si. $\hat{\mathrm{E}}$ um conflito da razão com a emoção, do instinto com o entendimento. Isso existe no homem de ontem e no de hoje. Nesse sentido, nada mudou durante o Contesado, nem no periodo da ditadura militar, tampouco mudará daqui para a frente. $\mathrm{O}$ que inquieta é o futuro da humanidade. (BASTOS, 2007, p. 95)

A partir do estudo de Os sertóes e de O bruxo do Contestado, nota-se a mudança da história da literatura brasileira, desde o século XIX até o momento presente, da constituição de um Novo Realismo elaborado a partir da revisão desse mesmo Realismo. Na perspectiva dessa nova visão, constatase a presença do autor implícito, que surge da união das categorias do autor como representante de uma realidade sensível e concreta e do narrador como criatura puramente ficcional e, portanto, objeto de linguagem e porta-voz de uma realidade ficcional. Assim, o limite entre personagem e autor tornase tênue e as semelhanças que os aproximam se deixam reconhecer. Tal transgressâo remete também para o processo de revisẫo do próprio contar, a partir da retomada de discursos múltiplos. A inovadora configuração proposta pelo Novo Realismo consiste, portanto, em fugir da relação de correspondência entre o acontecimento e sua descrição ficcional, e a literatura nos últimos trinta anos no panorama da história literária brasileira tende a problematizar ainda mais a relação entre o relato e o fato elaborando, assim, narrativas em que o que se inventa não é mais o ficcional, mas o real.

\section{REFERENCIAS}

BARTHES, Roland. O rumor da lingua. São Paulo: Brasiliense, 1988.

Bastos, Dau (Org.). Papos contemporâneos 1. Rio de Janeiro: Centro de Letras e Artes, Faculdade de Letras da Universidade Federal do Rio de Janeiro, 2007.

Bоотн, Wayne. A retórica da fiçção. São Paulo: Arcádia, 1980. 
CunHA, Euclides da. Os sertōes. Organizado por Leopoldo Bernucci. São Paulo: Ateliê Editorial, Imprensa Oficial do Estado, Arquivo do Estado, 2001.

Derrida, Jacques. A farmácia de Platão. São Paulo: Iluminuras, 2005.

Eco, Umberto. Pós-escrito a O Nome da Rosa. Rio de Janeiro: Nova Fronteira, 1985.

Olivera Neto, Godofredo de. O bruxo do Contestado. Rio de Janeiro: Nova Fronteira, 1996.

Com a palavra: o bruxo do Contestado. Jornal O Catarina!, FCC, 58 (XII), $11 / 12 / 2004$.

SANTANA, José C. Barreto de. Ciència e arte: Euclides da Cunha e as ciências naturais. Feira de Santana: Editora Hucitec, Universidade Estadual Feira de Santana, 2001.

SouzA, Ronaldes de M. A geopoética de Euclides da Cunha. [No prelo].

VALFNTE, Luis Fernando. Entre Clio e Caliope: a construção da narrativa histórica em Os sertóes. História, Ciências e Saúde: Manguinhos, v. 5, p. 39-55, jul. 1998. (Suplemento).

VALERY, Paul. Variedades, São Paulo: Iluminuras, 1999.

ZILıY, Bethold. A guerra como painel e espetáculo: a história encenada em Os sertōes. História, Ciências e Saúde: Manguinhos, v. 5, p. 13-37, jul. 1998. (Suplemento). 